\title{
THE TOXICITY OF EXTRACTS OF TEPHROSIA VIRGINIANA (FABACEAE) IN OKLAHOMA
}

\author{
Mary Gard \\ Oklahoma State University \\ Department of Botany \\ Stillwater, OK 74078-3013 \\ Email: gmary@okstate.edu
}

Keywords: fishkill, rotenone, piscicide, ethnobotany

\begin{abstract}
Historical usage of the roots of the legume Tephrosia virginiana as a piscicide by Native Americans has been documented. Due to questions about geographic variation in toxicity, an examination of the toxicity of six Oklahoma populations of the species was conducted. Rootstock extracts of plants in all populations exhibited acute toxicity in a standard laboratory bioassay using larval fathead minnows (Pimephales promelas). Isolation and identification of the compound or compounds responsible were not undertaken, however, toxicity is generally thought to be due to the presence of rotenone and related compounds. Although considerable variation in $\mathrm{LC}_{50}$ values exists among the six populations, this study produced few statistically significant differences. Correlations between plant toxicity and edaphic factors were not seen.
\end{abstract}

\section{INTRODUCTION}

Commonly known as hoary pea (Ibrahim 2000), goat's rue, catgut (Tyrl et al. 2008), and devil's shoestring (Swanton 1928), Tephrosia virginiana (Figure 1) is a member of the Fabaceae, or pea family. A native, perennial herb from woody rootstocks, it is distributed throughout the eastern half of the United States and extends westward to Iowa, and eastern Kansas, Oklahoma, and Texas (USDANRCS 2009). In Oklahoma it is most common in the eastern third, but can be found throughout the state. Populations are found in a variety of habitats in the Cross Timbers and prairies, with plants typically growing in sandy, well-drained soils (Tyrl et al. 2008). In addition, it is often associated with acidic soils (Steyermark 1963). Flowering time is from May to August, when the racemes of bicolored, papilionaceous flowers (Figure 2) produce legumes that are relished by wildlife (Tyrl et al. 2008).

Gard, M.

https://doi.org/10.22488/okstate.17.100076
Throughout most of its natural range, toxic compounds are absent in T. virginiana (Sievers et al. 1938), but in some populations, the roots contain the isoflavenoids rotenone, tephrosin, toxicarol, and other chemically similar compounds (Little et al. 1931). Rotenone is a wellknown piscicide, exerting its toxic effects by blocking the oxidation of NADH and preventing ATP from being converted into usable cellular energy (Lindahl \& Oberg 1961). Toxic populations occur in the southeastern states, and populations with the highest toxicity found thus far occur in the Carrizo Sands area of northeast Texas, an approximately 300-mile stretch from Caldwell County to Harrison County, where it widens out into Nacogdoches County to the east (Sievers et al. 1938). Previous tests on the plants of the species have revealed that the toxins are primarily sequestered in the underground portions. The seeds, however, have been found to contain rotenone, even in plants that were not otherwise toxic (Sievers et al. 1938). 


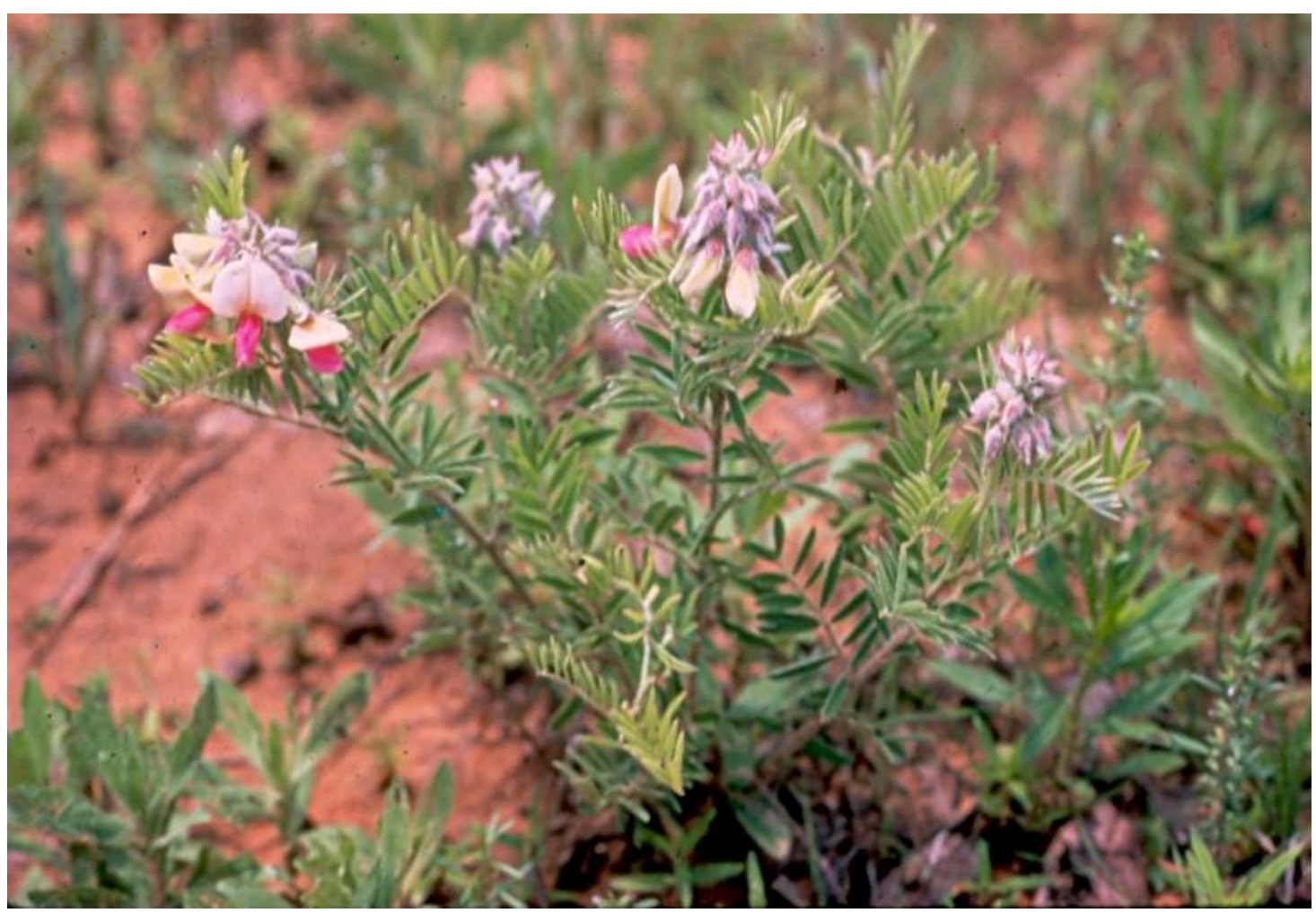

Figure 1 Tephrosia virginiana plant growing in Oklahoma. Photo courtesy of Ron Tyrl.

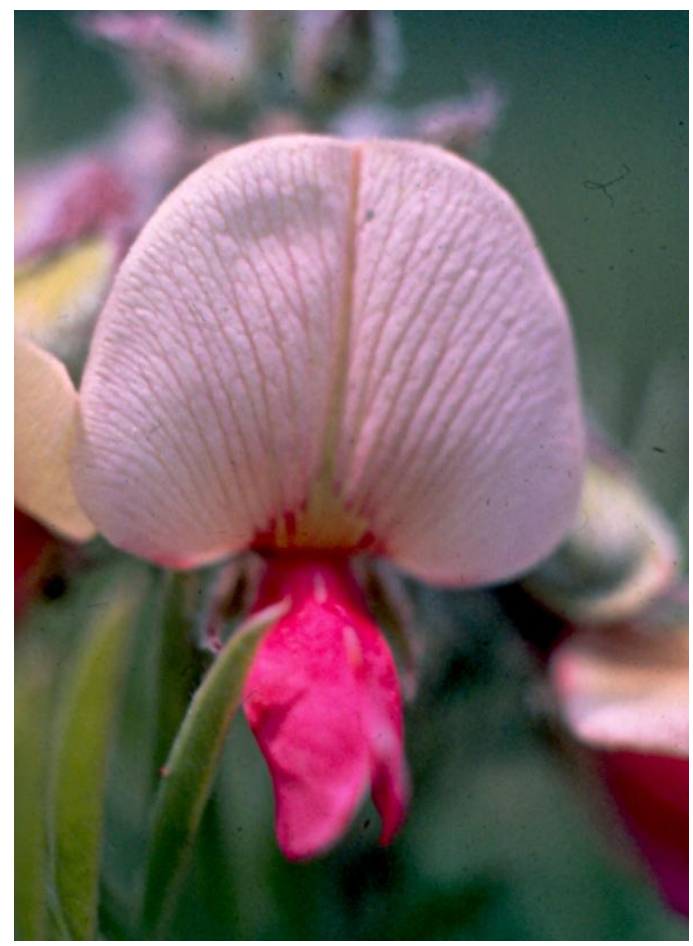

Figure 2 Individual flower of Tephrosia virginiana displaying a papilionaceous corolla. Photo courtesy of Ron Tyrl.
Historically, Native Americans in the Southeast (Florida, Tennessee, Mississippi, Alabama, and Georgia) used the roots of $T$. virginiana to stun fish to facilitate capture (Hudson 1976). The Cherokee, Creek, Seminole, Chickasaw, and Choctaw are documented as having used the plant. Among the first observers to report fishing with T. virginiana was James Adair, a Charleston trader, agent, and diplomat among the southeastern Indians of Mississippi from 1735 to 1768 (Hudson 1976). He observed that his Indian neighbors used plants to harvest fish in a process that was as much entertainment as labor.

In a dry summer season, they gather horse chestnuts and different kinds of roots, which having been thoroughly pounded pretty fine, and steeped a while in a trough, they scatter this mixture over the surface of a middle-sized pond, and stir it about with poles till the water is sufficiently

Gard, M. 
impregnated with the intoxicating bittern

(Williams 1930).

In 1906, Chitto Harjo, a Creek statesman, cited this activity in his famous plea that Creeks be allowed to "gather the wary fish" (Meserve 1933). Jennie Elrod (1924) of Oklahoma recorded in her diary that bound and dried T. viginiana roots were macerated and soaked in tubs of water overnight, and then scattered into a creek prior to a picnic (Figures 3 and 4). Numerous accounts of the plants being used in this manner include the writings of John Swanton, an ethnologist who studied the Creeks in the early 1900s. He wrote that among other plants used to stun fish, the devil's shoestring was used in pools isolated during the dry summer season. The roots were pounded directly on a hard surface, such as a fallen log, over the water surface to allow the juices to fall into the still pools or slow-flowing waterways (Swanton 1928). Following the relocation of the Indian tribes to Oklahoma in the 1830s, use of $T$.

virginiana in fishing continued (Elrod 1924). As illustrated in a photographic atlas compiled in Oklahoma at the turn of the Twentieth Century, fishkills were a muchenjoyed sporting occasion until the practice was banned in 1915 (Gettys and Watkins 1984).

Despite these historical accounts of the apparent toxicity of $T$. virginiana, there are questions as to the toxicity of plants found in Oklahoma. In interviews recorded in The Indian-Pioneer Papers (Works Progress Administration 1937), Jefferson Berryhill, a member of the Muscogee (Creek) tribe, stated that roots from sandy areas (vs. rocky areas) were preferred and seemed to be "more virulent" in their poisoning abilities (Foreman 1938). Prior to this investigation, the most recent toxicity study involving Oklahoma populations of T. virginiana was conducted in the 1930s. Sievers and Russell (1938) investigated populations throughout the eastern United States and as far west as Oklahoma and Texas. They classified Oklahoma populations as "secondary" in nature, indicating that toxic plants were found infrequently in these populations and only under special circumstances. Specifically, they found that toxic plants occurred either in 'bald spots' where some factor, e.g., road construction or water erosion, had interfered with the normal development of the soil profile or sites where the roots of T. virginiana were in close proximity to those of other plants, especially oak roots. They considered these populations to be of little value for the commercial production of insecticide, an objective of their survey. Their observations thus contradict the historical accounts of fishkills by Native Americans in Oklahoma using T. virginiana.

Because of this apparent contradiction, this study was undertaken to investigate the toxicity of T. virginiana in Oklahoma. The work involved: (1) reviewing the literature of its historical use in Oklahoma; (2) locating Oklahoma populations; (3) collecting plants; (4) extracting from the rootstocks the compound or compounds responsible for toxicity; and (5) conducting bioassays for toxicity.

Gard, M. 


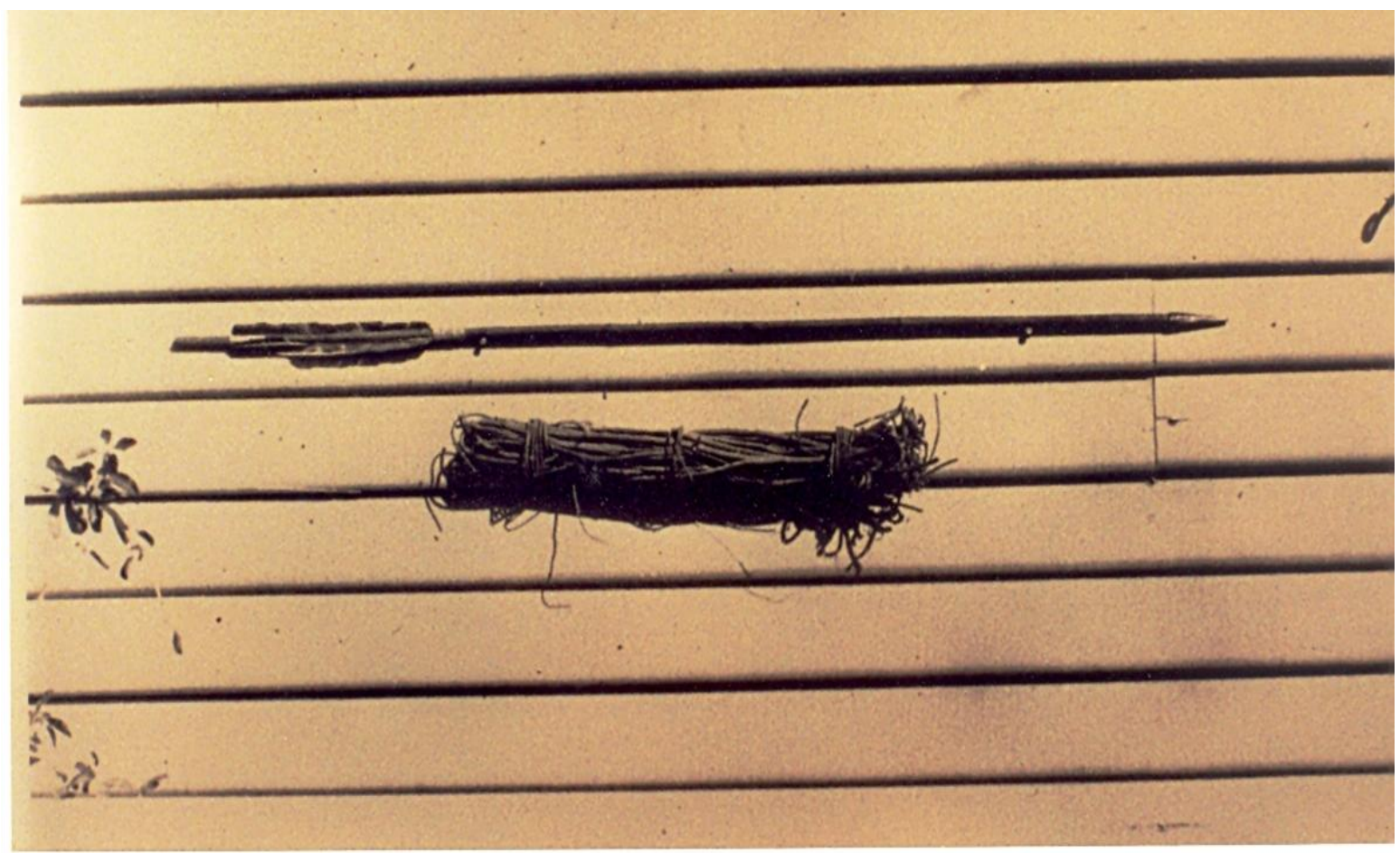

Figure 3 Bundled root of Tephrosia virginiana next to an arrow used in a fishkill in Okmulgee, Oklahoma, 1924. Photo by Jennie Elrod and courtesy of the Archives and Manuscripts Division of the Oklahoma Historical Society.

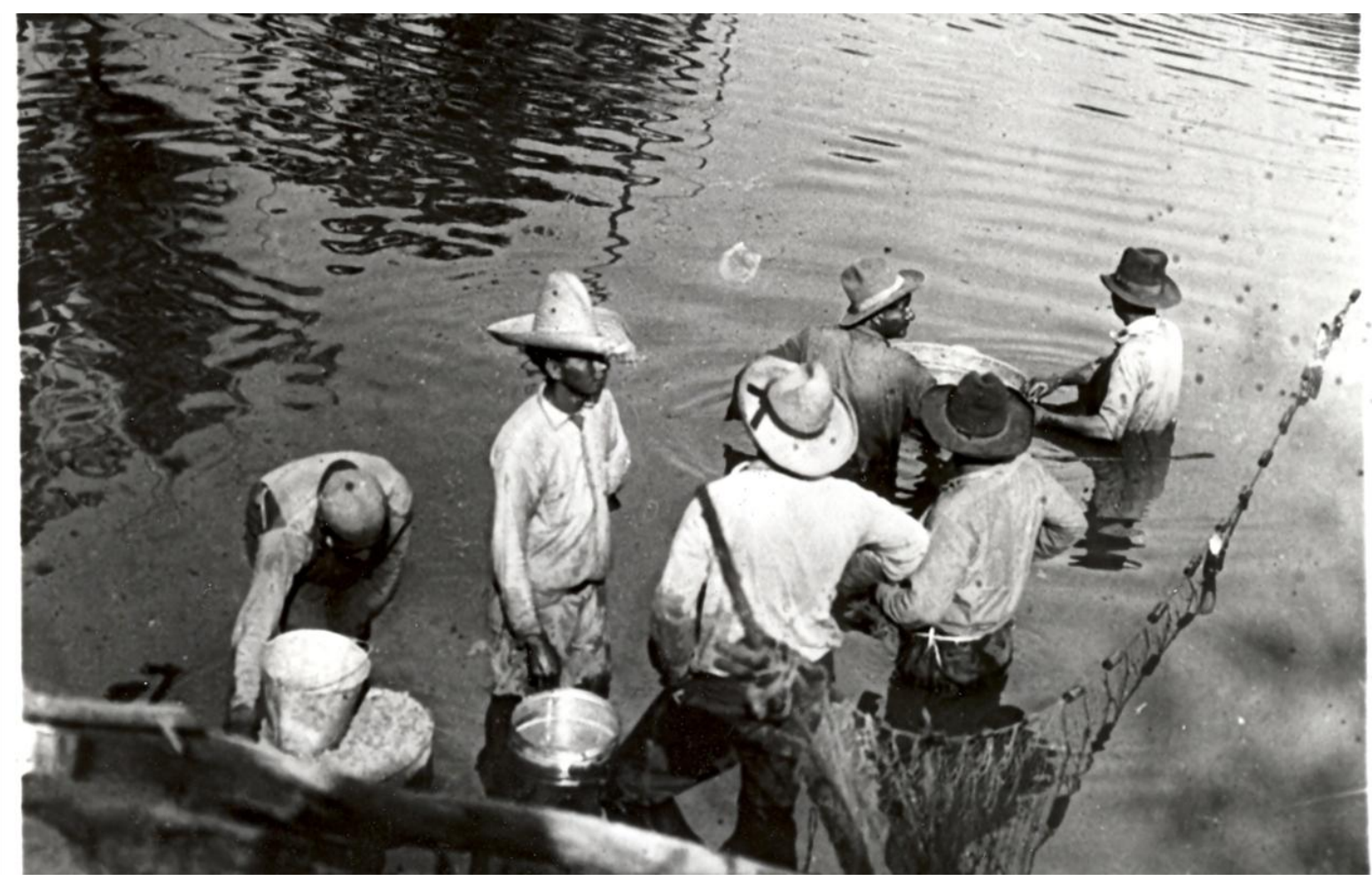

Figure 4 Creek tribesmen "going into the water with tubs of ground devil's shoestring, Aug 24, 1924”, Okmulgee, Oklahoma. Photo by Jennie Elrod and courtesy of the Archives and Manuscripts Division of the Oklahoma Historical Society.

Gard, M. 


\section{METHODOLOGY}

\section{Plant Collection}

In order to examine the toxicity of $T$. virginiana, populations were located throughout the state using label information from herbarium specimens deposited in the OSU Herbarium (OKLA). During the 2007 growing season, the rootstocks (woody, underground stem base and/or root apex giving rise to aerial growth each season) of 3 or 4 plants were collected from each of six locations in five counties: Adair, Atoka, Cherokee, Okmulgee, and Osage (Figure 5; Table 1). As the plants were collected, surface soil samples also were collected. They were placed in paper bags and allowed to air dry for several weeks, after which they underwent routine tests for $\mathrm{pH}$, organic matter (OM\%), $\mathrm{K}$ index, $\mathrm{P}$ index, and soil texture at the Oklahoma State University Soil Water and Forage Analytical Laboratory (Stillwater, OK.).

\section{Compound Extraction}

Specimens were dried by placing them in paper bags at room temperature for two weeks. When completely dry, they were processed via a Soxhlet system using the protocol of Sievers and Russell (1938), which has long been used to extract toxic compounds from Tephrosia. This protocol was modified by the use of a SPEX ${ }^{\circledR}$ SamplePrep Freezer/Mill (SPEX ${ }^{\circledR}$
CertiPrep, Metuchen, NJ) to grind the dried roots cryogenically in order to prepare them for the extraction procedure. The freezer/mill was used due to the difficulty encountered during initial attempts to pulverize the long, tough lateral roots and woody rootstock.

All plant samples were ground to a fineness of \#100 mesh using Tyler mesh sieves (Tyler Screening Company, Canada). Additional particle sizes used in the extraction were \#20 and \#200 mesh from the Beggs population in order to determine if root particle size would affect toxicity. Following the protocol of Sievers (1938), extracts were standardized to be equivalent to $1.5 \mathrm{~g}$ of ground sample per $100-\mathrm{mL}$ of acetone solution in all samples. Rotenone is known to break down quite readily in water upon exposure to air and sunlight (Barnes and Freyre 1967). Therefore, using an acetone solution allowed for the quantification of sample as well as an extension of the natural shelf-life of the compounds. An acetone blank - a solution of acetone without any plant material included - was also used in the extraction as a control to rule out the toxic effects acetone may have had in the bioassay. All extracts were stored in a $25^{\circ} \mathrm{C}+/-1^{\circ} \mathrm{C}$ $\left(77^{\circ} \mathrm{F}+/-1.8^{\circ} \mathrm{F}\right)$ room in foil-covered amber glass bottles between assays to reduce exposure to light.

Figure 5 County sites in Oklahoma where populations of Tephrosia virginiana were sampled to test for piscicidal effects of root extracts.

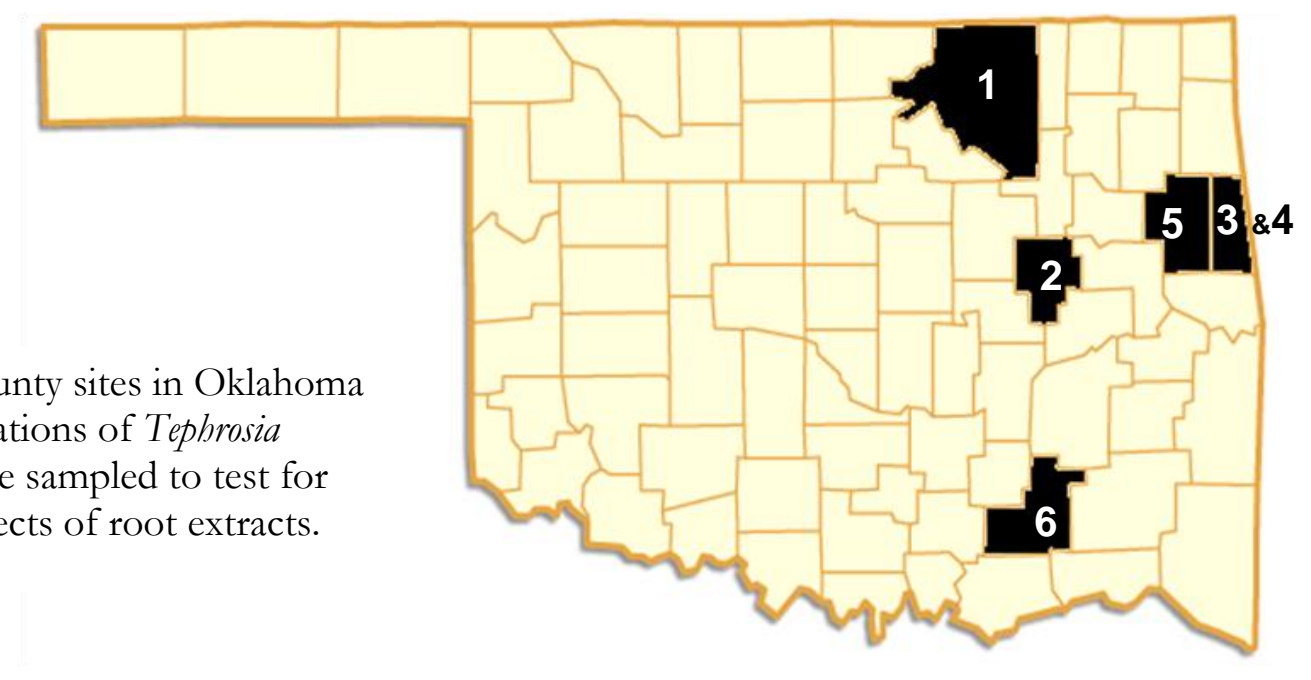

Gard, M. 
Table 1 Locality information for sampling sites where Tephrosia virginiana specimens were collected in Oklahoma.

\begin{tabular}{|c|c|c|c|c|c|c|c|}
\hline & Site name & County & $\begin{array}{l}\text { GPS } \\
\text { coordinates }\end{array}$ & Mileage & Habitat & $\begin{array}{l}\text { Date } \\
\text { collected }\end{array}$ & $\begin{array}{l}\text { Ecological } \\
\text { notes }\end{array}$ \\
\hline 1 & $\begin{array}{l}\text { Osage- } \\
\text { Tallgrass } \\
\text { Prairie } \\
\text { Preserve } \\
\text { (TGPP) }\end{array}$ & Osage & $\begin{array}{l}36^{\circ} 50^{\prime} 34.26^{\prime \prime} \mathrm{N} \\
96^{\circ} 24^{\prime} 25.37^{\prime \prime} \mathrm{W}\end{array}$ & $\begin{array}{l}1 \mathrm{~km} \text { SE of } \\
\text { TGPP HQ }\end{array}$ & $\begin{array}{l}\text { on side of } \\
\text { a large hill } \\
\text { in a } \\
\text { tallgrass } \\
\text { prairie }\end{array}$ & 05/22/07 & $\begin{array}{l}\text { evidence of } \\
\text { burn earlier in } \\
\text { the year (some } \\
\text { stems were } \\
\text { blackened); } \\
\text { soils extremely } \\
\text { rocky }\end{array}$ \\
\hline 2 & Beggs & Okmulgee & $\begin{array}{l}35^{\circ} 44^{\prime} 24.59^{\prime \prime} \mathrm{N} \\
96^{\circ} 01^{\prime} 08.81^{\prime \prime} \mathrm{W}\end{array}$ & $\begin{array}{l}\text { near road } \\
\text { cut off hwy } \\
75 ; 2.5 \mathrm{~km} \\
\text { E of Beggs, } \\
\text { OK }\end{array}$ & $\begin{array}{l}\text { edge of } \\
\text { fallow field } \\
\text { under } \\
\text { fence row }\end{array}$ & $06 / 16 / 07$ & $\begin{array}{l}\text { soil shallow } \\
\text { and disturbed } \\
\text { from erosion }\end{array}$ \\
\hline 3 & $\begin{array}{l}\text { Adair- } \\
\text { Gittin'Down } \\
\text { Mtn. (GDM) }\end{array}$ & Adair & $\begin{array}{l}35^{\circ} 45^{\prime} 57.31^{\prime \prime} \mathrm{N} \\
94^{\circ} 43^{\prime} 50.68^{\prime \prime} \mathrm{W}\end{array}$ & $\begin{array}{l}\text { approx. } 1 \\
\text { km W of } \\
\text { Bunch Rd. } \\
\text { S of Hwy } \\
100 ; 9.5 \mathrm{~km} \\
\text { SW of } \\
\text { Stillwell, OK }\end{array}$ & $\begin{array}{l}\text { understory } \\
\text { of Oak- } \\
\text { hickory } \\
\text { forest on } \\
\text { bluff } \\
\text { above } \\
\text { Charley } \\
\text { Owl Cave }\end{array}$ & $06 / 23 / 07$ & $\begin{array}{l}\text { dense litter in } \\
\text { area; limestone } \\
\text { parent material; } \\
\text { soil rocky; } \\
\text { gently sloping } \\
\text { topographic } \\
\text { situation }\end{array}$ \\
\hline 4 & $\begin{array}{l}\text { Adair- Eagle } \\
\text { Pass (EP) }\end{array}$ & Adair & $\begin{array}{l}35^{\circ} 42^{\prime} 48.00^{\prime \prime} \mathrm{N} \\
94^{\circ} 32^{\prime} 05.96^{\prime \prime} \mathrm{W}\end{array}$ & $\begin{array}{l}\text { Eagle Pass } \\
\text { Hollow area } \\
\text { near 'Jesus } \\
\text { Saves' } \\
\text { rock; N of } \\
\text { county road } \\
\text { E 0900; } 4.5 \\
\text { km SE of } \\
\text { Stillwell, OK }\end{array}$ & $\begin{array}{l}\text { understory } \\
\text { of Oak- } \\
\text { Hickory } \\
\text { forest on } \\
\text { slope } \\
\text { leading to } \\
\text { Eagle } \\
\text { Pass } \\
\text { Creek }\end{array}$ & $06 / 22 / 07$ & $\begin{array}{l}\text { area burned in } \\
\text { spring of } \\
\text { collection year; } \\
\text { steeply sloping } \\
\text { topographic } \\
\text { situation }\end{array}$ \\
\hline 5 & $\begin{array}{l}\text { Cherokee- } \\
\text { Sparrowhawk } \\
\text { Primive Area } \\
\text { (SPA) }\end{array}$ & Cherokee & $\begin{array}{l}35^{\circ} 57^{\prime} 33.34^{\prime \prime} \mathrm{N} \\
94^{\circ} 54^{\prime} 09.63^{\prime \prime} \mathrm{W}\end{array}$ & $\begin{array}{l}\text { SPA about } \\
1 \mathrm{~km} E \text { of of } \\
\text { Hwy } 10 \\
\text { near } \\
\text { Tahlequah, } \\
\text { OK near } \\
\text { the Illinois } \\
\text { river }\end{array}$ & $\begin{array}{l}\text { understory } \\
\text { of Pine } \\
\text { Oak } \\
\text { hickory } \\
\text { forest } \\
\text { near } \\
\text { mouth of } \\
\text { SPA trail }\end{array}$ & $09 / 15 / 07$ & $\begin{array}{l}\text { limestone } \\
\text { parent material; } \\
\text { soil rocky; } \\
\text { steeply sloping } \\
\text { topographic } \\
\text { situation }\end{array}$ \\
\hline 6 & $\begin{array}{l}\text { Atoka -Little } \\
\text { Bugaboo } \\
\text { Creek } \\
\text { Overlook } \\
\text { (LBCO) }\end{array}$ & Atoka & $\begin{array}{l}34^{\circ} 24^{\prime} 00.18^{\prime \prime} \mathrm{N} \\
95^{\circ} 50^{\prime} 02.59^{\prime \prime} \mathrm{W}\end{array}$ & $\begin{array}{l}\text { Near Little } \\
\text { Bugaboo } \\
\text { Canyon } \\
\text { recreational } \\
\text { overlook in } \\
\text { McGee } \\
\text { Creek State } \\
\text { Park; } 10 \mathrm{~km} \\
\text { SE of } \\
\text { Atoka, OK }\end{array}$ & $\begin{array}{l}\text { understory } \\
\text { of mixed } \\
\text { hardwood } \\
\& \text { Pine } \\
\text { forest }\end{array}$ & $10 / 25 / 07$ & $\begin{array}{l}\text { dense litter in } \\
\text { area; limestone } \\
\text { parent material; } \\
\text { soil rocky; } \\
\text { nearly level } \\
\text { topography }\end{array}$ \\
\hline
\end{tabular}

Gard, M. 


\section{Laboratory Bioassays}

Acute laboratory toxicity tests followed methods outlined in USEPA (2002) using the fathead minnow (Pimephales promelas) and were conducted under Oklahoma State University Animal Care and Use Protocol AS50110. Larval fish (<24 hours old) were exposed to dilutions $(.01,0.1,1.0$, and 10 $\mathrm{mg} / \mathrm{L}$ ) of plant extract in moderately hard (MH) formulated water (USEPA 2002). Additionally, two control test concentrations were used, the first consisting of an acetone blank solution (concentration of $10 \mathrm{mg} / \mathrm{L}$ in moderately hard formulated water), and the second of pure, moderately hard formulated water. All exposures were conducted in $250-\mathrm{mL}$ glass bowls containing $200-\mathrm{mL}$ of test solution, 10 fathead minnows per bowl, and two replicate bowls per test concentration. Test chambers were inspected every $24 \mathrm{~h}$ to determine the numbers of live and dead fish, with dead fish identified by discoloration and lack of response to gentle prodding. Test solutions were renewed every 24 h by replacing $80 \%$ of the water volume with freshly prepared extract solutions. Test temperature was maintained in a temperature controlled room at $25^{\circ} \mathrm{C}$ $+/-1^{\circ} \mathrm{C}\left(77^{\circ} \mathrm{F}+/-1.8^{\circ} \mathrm{F}\right)$ with a $16 / 8 \mathrm{~h}$ light/dark cycle. Effects of Median Lethal Concentrations (48-hr LC 50 values) were calculated using Comprehensive Environmental Toxicity Information System software (CETIS version 1.1.1, Tidepool Scientific Software, McKinleyville, CA). Tests were conducted as larval fish became available over a several month period beginning in July of 2007 and concluding in July of 2008. All samples were tested at least 4 times. Osage, Adair GDM, Beggs \#20, and Beggs \# 200 were tested 5 times each (Table 2).

\section{Laboratory Water Chemistry}

Temperature, dissolved oxygen (DO), $\mathrm{pH}$, total ammonia, conductivity, alkalinity, and hardness were measured in each test solution at the start of each bioassay and at the beginning and end of each solution renewal cycle; $\mathrm{pH}$ was measured every $6 \mathrm{~h}$ throughout the tests. Ammonia was measured using an Accument ${ }^{\circledR}$ AR25 Ammonia Meter (Fisher Scientific, New Jersey, USA), with unionized ammonia concentrations estimated from the measured total values based on temperature and $\mathrm{pH}$. Dissolved oxygen was measured using a YSI ${ }^{\circledR}$ model 550A Dissolved Oxygen meter (YSI Incorporated, Ohio, USA), and $\mathrm{pH}$ was measured using a Accument ${ }^{\circledR}$ portable AP $62 \mathrm{pH} / \mathrm{mV}$ meter (Fisher Scientific, Pittsburg, Pennsylvania). Conductivity was measured with a $\mathrm{Hach}{ }^{\circledR}$ conductivity/TDS meter (Hach, Loveland, Colorado), and alkalinity and hardness were measured by titration (APHA 1998). Prior to use, all water quality meters were calibrated according to the manufacturer instructions.

\section{Statistics}

Statistical tests for normality or heterogeneity of variance - Kruskal-Wallis One-WAY ANOVA on Ranks followed by Dunn's Post-hoc method - were performed to determine if any significant differences in 48-hr LC $_{50}$ values existed between sample sites. Differences between the sites were regarded to be significant if $P<0.05$. In addition, to determine the strength of the relationship between 48 -hr $\mathrm{LC}_{50}$ values and various soil parameters, a simple linear regression was calculated and subsequently, a multiple linear regression. The regression equations were considered to be significant if the output $P<0.05$.

\section{RESULTS}

Acute toxicity was observed in all samples tested, with the exception of the acetone blank and the pure $\mathrm{MH}$ water, where no mortality occurred. Because of the variability among the values generated from the replicate bioassays within sites (see

Gard, M. 
Table 2), there were few statistically significant differences in toxicity. Of these differences detected, the extracts from Adair Eagle Pass site and Atoka were significantly more toxic than the extract from Cherokee County $(P<0.05)$. The extract from Atoka was also significantly more toxic than the extract from Beggs. Some extracts varied in toxicity over time, with $48-\mathrm{hr} \mathrm{LC}_{50}$ values showing increases and decreases, whereas other extracts were more consistent (see Table 2). On average, the Cherokee sample was the least toxic, and Adair Eagle Pass and Atoka were found to have equivalent 48-hr LC $_{50}$ values, as well as having the most consistent 48-hr $\mathrm{LC}_{50}$ values throughout the testing. Extracts from plant material that was ground finer (Beggs \#200 mesh) exhibited the same toxicity as the standard particle size from the same collection site; plant material ground coarser (Beggs \#20 mesh) exhibited higher average 48-hr $\mathrm{LC}_{50}$ values. These data are displayed in Figure 6, along with the standard deviation.

No relationships between toxicity and the five soil parameters examined - soil texture, $\mathrm{pH}, \mathrm{OM} \%, \mathrm{~K}$ index, or $\mathrm{P}$ index were detected. The regression equations calculated were not significant.

Table 2 48-hr $\mathrm{LC}_{50}(\mathrm{mg} / \mathrm{L})$ values for Fathead minnows (Pimephales promelas) exposed to root extracts of Tephrosia virginiana from different six sites in Oklahoma. An acetone blank and a pure water solution used as controls exhibited no toxicity.

\begin{tabular}{|c|c|c|c|c|c|}
\hline \multirow[b]{2}{*}{ Location } & \multicolumn{5}{|c|}{$\begin{array}{l}48-\mathrm{hr} \mathrm{LC}_{50} \text { values }(\mathrm{mg} / \mathrm{L}) \\
\text { (concentration lethal to } 50 \% \text { of fish within } 48 \text { hours) }\end{array}$} \\
\hline & Test 1 & Test 2 & Test 3 & Test 4 & Test 5 \\
\hline $\begin{array}{l}\text { Beggs } \\
\# 20 \text { mesh }\end{array}$ & $\begin{array}{l}0.32 \\
(0.17-0.59)\end{array}$ & $\begin{array}{l}0.79 \\
(0.39-1.62)\end{array}$ & $\begin{array}{l}1.58 \\
(0.99-2.54)\end{array}$ & $\begin{array}{l}1.00 \\
(0.48-2.07)\end{array}$ & $\begin{array}{l}1.00 \\
(0.48-2.07)\end{array}$ \\
\hline $\begin{array}{l}\text { Beggs } \\
\# 100 \text { mesh }\end{array}$ & $\begin{array}{l}2.51 \\
\text { (C.I. NR) }\end{array}$ & $\begin{array}{l}2.51 \\
(1.62-3.89)\end{array}$ & - & $\begin{array}{l}2.51 \\
(1.62-3.89)\end{array}$ & $\begin{array}{l}2.51 \\
(1.62-3.89)\end{array}$ \\
\hline $\begin{array}{l}\text { Beggs } \\
\# 200 \text { mesh }\end{array}$ & $\begin{array}{l}0.32 \\
\text { (C.I. NR) }\end{array}$ & $\begin{array}{l}3.16 \\
\text { (C.I. NR) }\end{array}$ & $\begin{array}{l}0.71 \\
(0.43-1.16)\end{array}$ & $\begin{array}{l}0.79 \\
(0.39-1.62)\end{array}$ & $\begin{array}{l}1.00 \\
(0.48-2.07)\end{array}$ \\
\hline $\begin{array}{l}\text { Adair } \\
\text { Eagle Pass }\end{array}$ & $\begin{array}{l}0.32 \\
\text { (C.I. NR) }\end{array}$ & $\begin{array}{l}0.32 \\
\text { (C.I. NR) }\end{array}$ & - & $\begin{array}{l}0.32 \\
\text { (C.I. NR) }\end{array}$ & $\begin{array}{l}0.28 \\
\text { (C.I. NR) }\end{array}$ \\
\hline $\begin{array}{l}\text { Adair } \\
\text { Gittin' Down Mtn. }\end{array}$ & $\begin{array}{l}2.80 \\
(2.21-3.56)\end{array}$ & $\begin{array}{l}1.0 \\
(0.48-2.07)\end{array}$ & $\begin{array}{l}1.12 \\
(0.67-0.87)\end{array}$ & $\begin{array}{l}1.26 \\
(0.62-2.57)\end{array}$ & $\begin{array}{l}2.51 \\
(1.62-3.89)\end{array}$ \\
\hline Atoka & $\begin{array}{l}0.46 \\
(0.31-0.7)\end{array}$ & $\begin{array}{l}0.40 \\
(0.26-0.62)\end{array}$ & - & $\begin{array}{l}0.40 \\
(0.26-0.62)\end{array}$ & $\begin{array}{l}0.32 \\
\text { (C.I. NR) }\end{array}$ \\
\hline Cherokee & $\begin{array}{l}4.62 \\
(2.54-8.38)\end{array}$ & $\begin{array}{l}3.16 \\
\text { (C.I. NR) }\end{array}$ & - & $\begin{array}{l}3.16 \\
\text { (C.I. NR) }\end{array}$ & $\begin{array}{l}2.51 \\
(1.62-3.89)\end{array}$ \\
\hline Osage & $\begin{array}{l}0.30 \\
\text { (C.I. NR) }\end{array}$ & $\begin{array}{l}2.51 \\
(1.62-3.89)\end{array}$ & $\begin{array}{l}1.12 \\
(0.67-0.87)\end{array}$ & $\begin{array}{l}2.00 \\
(1.11-3.57)\end{array}$ & $\begin{array}{l}2.00 \\
(1.11-3.57)\end{array}$ \\
\hline
\end{tabular}




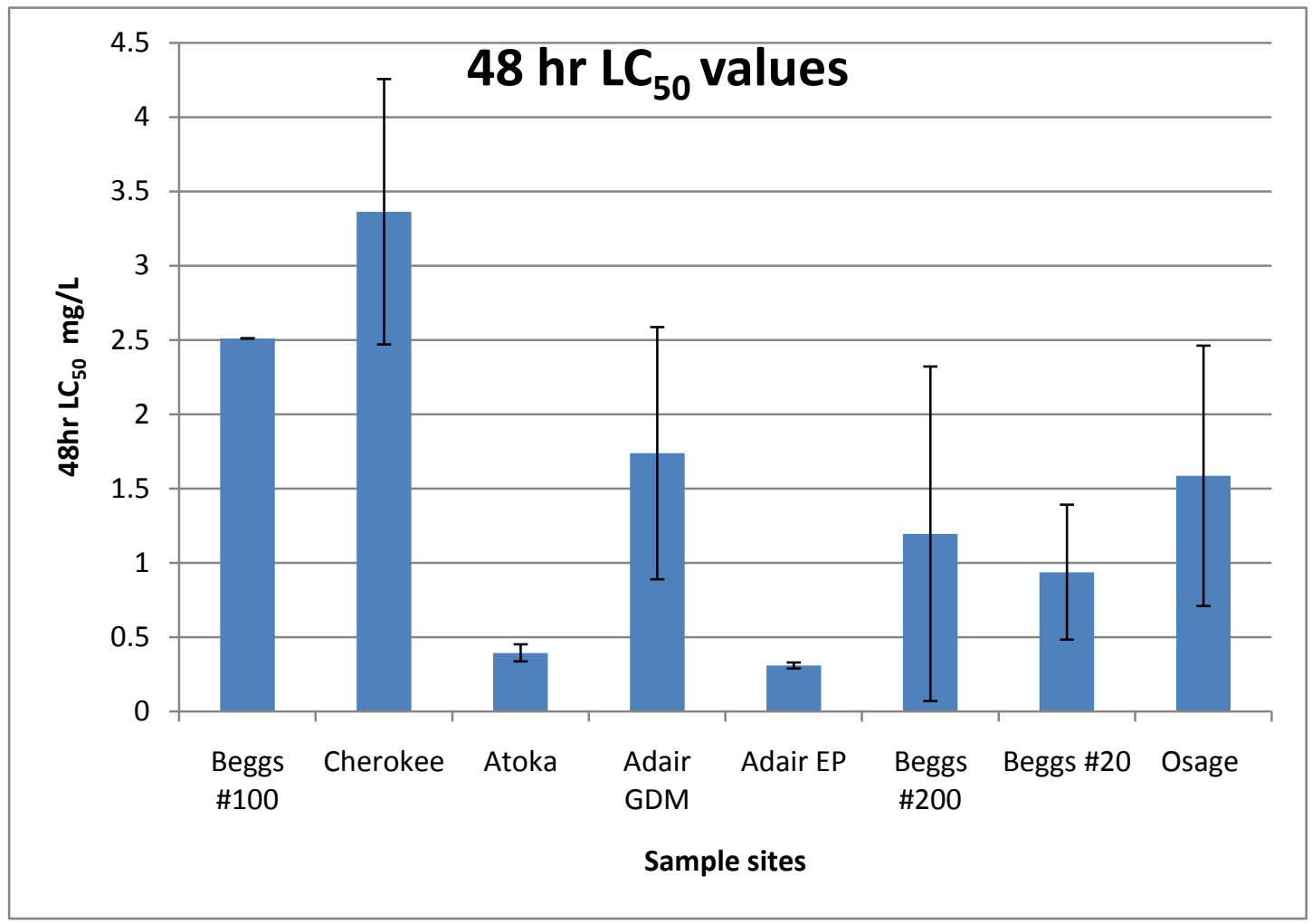

Figure 6 Mean 48-hr $\mathrm{LC}_{50}$ values and standard deviation bars for root extracts of Tephrosia virginiana from six sites in Oklahoma.

\section{DISCUSSION}

The six Oklahoma populations of $T$. virginiana tested in this study appear to contain a toxin (or toxins) that results in the mortality of fish in laboratory experiments. All extracts containing plant material produced mortality of larval fathead minnows in a standard laboratory bioassay (see Table 2; Figure 6). Because the objective of this preliminary study was to determine only if a toxin or toxins were present in Oklahoma populations, an attempt to isolate and identify the compound or compounds responsible was not undertaken.

The variability among the replicates within sites produced few statistically significant differences among the six populations (see Table 2). Degradation of the toxin or toxins with time is certainly a possibility (Barnes and Freyre 1967); however, there must be some persistance of the toxic compounds because Native Americans collected, dried, and stored the roots for varying lengths of time (Foreman 1938). A possible source of error is in the grinding process. Various portions of the rootstock might have been indiscriminately distributed in the particle size samples from Beggs collection site. It is not known if toxins are more prominent in the dermis or pith, for example, and this could have been a reason that particle size toxicity seemed to be uneven in relation to size .

Jefferson Berryhill's memory that roots from sandy area were preferred and seemed "more virulent" in their poisoning abilities (Works Progress Administration 1937; Foreman 1938) suggests that edaphic factors may play a role in toxicity of T. virginiana. Sievers and his coworkers (1938) likewise suggested that differences in toxicity might be related to soil and/or influences by other

Gard, M. 
plants. In this investigation, no relationships between toxicity and the five soil parameters examined were detected. However, because of the limited sample size and the variability in toxicity among the five populations, an understanding of the possible influence of edaphic influences requires that the preliminary work outlined here be repeated and extended.

\section{ACKNOWLEDGMENTS}

This study represents one part of a master's thesis submitted to the graduate faculty of Oklahoma State University. Partial support for field work was provided by the J. K. McPherson Memorial Fund. I thank the Oklahoma State Historical Society for permission to use the photos of Native Americans fishing with Tephrosia. I would also like to thank Dr. Ron Tyrl, Dr. Becky Johnson, Dr. Joseph Bidwell, Dr. Byron Sudbury, and Naomi Cooper for assistance on this project.

\section{LITERATURE CITED}

APHA. 1998. Standard Methods for the Examination of $W$ ater and $W$ astewater. $20^{\text {th }}$ Edition. United Book Press Inc. Baltimore, MD.

Barnes, D. and R. H. Freyre. 1967. Recovery of natural insecticides from Tephosia vogelii. III. An improved procedure for sampling and assaying rotenoid Content in leaves. Economic Botany. Vol. 21: 93-98.

Elrod, J. 1924. Diary of Jennie Elrod. Archives and Manuscripts Division of the Oklahoma Historical Society, Oklahoma City, OK.

Foreman, G. 1938. Indian Pioneer History. Oklahoma Historical Society, Oklahoma City, OK.

Gettys, M. and J. Watkins. 1984. A photographic study of creek floodways in the 1920's. Papers in Anthropology 24(12):113-129. University of Oklahoma, Norman, OK.
Hoagland B. W., A. K. Buthod, I. H. Butler, P. H. C. Crawford, A. H. Udasi, W. J. Elisens, and R. J. Tyrl. 2004. Oklahoma Vascular Plants Database (http://geo.ou.edu/botanical, April 2009).) Oklahoma Biological Survey, University of Oklahoma, Norman, OK.

Hudson, C. 1976. The Southeastern Indians. The University of Tennesee Press, Knoxville, TN.

Ibrahim, B., B. M'batchi, H. Mounzeo, H. P. Bourobou Bourobou, and P. Posso. 2000. Effect of Tephrosia vogelii and Justicia extensa on Tilapia nilotica in vivo. Journal of Ethnopharmacology 69(2):99-104.

Lindahl, P. E. and K. E. Öberg. 1961. The effect of rotenone on respiration and its point of attack. Experimental Cell Research 23:228-237.

Little, V. A. 1931. Devil's shoestring as an insecticide. Science. 73:315-316.

Meserve, J.B. 1933. The plea of Crazy Snake (Chitto Harjo). Chronicles of Oklahoma, Volume XI, No. 33.

Sievers, A. F., G. A. Russell, M. S. Lowman, E. D. Fowler, C. O. Erlanson, and V. A. Little. 1938. Studies on the possibilities of devil's shoestring (Tephrosia virginiana) and other native species of Tephrosia as commercial sources of insecticides. Technical Bulletin No. 595. United States Department of Agriculture, Washington, D.C.

Steyermark, J. A. 1963. Flora of Missouri. The Iowa State University Press, Ames, IA.

Swanton, J. N. 1928. Social organization and social usage of the Indians of the Creek Confederacy. Forty-Second Annual Report of the Bureau of American Ethnology to the Secretary of the Smithsonian Institution, 19241925. Government Printing Office, Washington D.C.

Tyrl, R. J., T. G. Bidwell, R. E. Masters, and R. D. Elmore. 2008. Field Guide to Oklahoma Plants. 2nd Edition. Oklahoma State University, Stillwater, OK. 
US Environmental Protection Agency. 2002. Methods for Measuring the Acute Toxicity of Effluents to Freshwater and Marine Organisms. 5th Edition. United States Environmental Protection Agency, Office of Water. Washington D.C. EPA 821-R02-012.

USDA, NRCS. 2009. The PLANTS

Database (http://plants.usda.gov, 10 September 2009). National Plant Data Center, Baton Rouge, LA.
Williams, S. C., ed. 1930. Adair's History of the American Indians. Promontory Press, New York. (Adair's original work was published in London in 1775.)

Works Progress Administration. 1937. The Indian Pioneer Papers. University of Oklahoma Western History Collection, Norman, OK.

Gard, M. 